\title{
Refugee Stories: Constructing a Bosnian Girl's Identity in Exile-a Case Study
}

\author{
Eija Asikainen
}

\begin{abstract}
The breakup of Yugoslavia turned into a violent civil war in Bosnia in the summer of 1991. The war did not begin as ethnic conflict, but ethnic traits were defined and collective memories were manipulated to mobilize people and to justify the violence between groups. In the case of Bosnian refugees, the questions concerning ethnicity and identity are especially important. The objective of this paper is to discuss the constitution of the refugee identity of an adolescent Bosnian girl in the context of exile. The research methods used were collection of refugee stories and participant observation. By collecting refugee stories, it is possible to examine the processes of identity constitution and the flexibility of identities.
\end{abstract}

Précis

La partition de la Yougoslavie a entraîné une virulente guerre civile en Bosnie à l'été 1991. La guerre ne s'est pas amorcée comme un conflit ethnique, mais des caractéristiques ethniques ont éventuellement été invoquées, et la mémoire collective a été manipulée pour mobiliser les populations et légitimer la violence entre groupes. Dans le ces des réfugiés bosniaques, les questions d'ethnicité et d'identité sont particulièrement sensibles. Le but du présent article est de procéder à une présentation de l'identité de réfugiée d'une jeune adolescente bosniaque dans le contexte de l'exil. Les méthodes de recherche utilisées ont été la collecte de récits de réfugiés et l'observation directe. La collecte de récits de réfugiés a rendu possible l'examen des processus de constitution d'identité et la flexibilité de ces identités.

Eija Asikainen is a researcher and Ph.D. candidate at the Faculty of Education, the University of Joensuu, Joensuu, Finland.

\section{Introduction}

The breakup of Yugoslavia resulted in a violent civil war in Bosnia in the summer of 1991. In the media, two main approaches were used in reporting and explaining the events in Bosnia. The first approach explained the war as the rise of centuries-old hatreds. According to this line of thought, people in Bosnia-Herzegovina have always hated each other, but tolerance and coexistence were imposed by the communist regime. The alternative idealistic explanation, however, conceptualizes Bosnia as a multicultural society in which the diverse religious and ethnic groups lived together in peace and harmony, and did not classify themselves in terms of "Serb," "Croat" or "Muslim." Presumably neither of these explanations was true. Both tolerance and prejudice between individuals and between different groups existed in Bosnia. The attitudes towards religion and ethnicity depended on the sociocultural background in which the person had grown up and lived (Bringa 1995, 3). The conflict resulted from political, economic and anthropological factors interacting in an unfortunate way. The creation of enemies.was a prerequisite for war, and this was done by transferring latent tensions into acute ones and using the media to create and maintain existential insecurity. The war did not begin as an ethnic conflict, but collective memories were manipulated, and ethnic traits were defined and used as a weapon to justify violence towards other groups. Nationalism was offered as an answer to the search for identity and the crisis in the system of morals and values (Radosevic 1996, 66).

This discussion shows that ethnicity was an important factor in mobilizing people in the Bosnian war. The war was organized elsewhere, but with nationalist manipulation, people living in the villages were involved in the war to fight for their villages and their families. Ethnicity is an important element in an identity and life history of an individual. In this paper, ethnicity is seen as an ethnoreligious affiliation. It is a process that is created, manipulated and negotiated during the life history. Identity is seen as constituted and reconstituted by narrative that shifts over time, place and audience.

The first Bosnian Muslim refugees arrived in North Carelia, Finland, in the autumn of 1992, and in the spring of 1993. These refugees came from villages in Northern Bosnia, an area that under the Dayton Peace Agreement remained under Serbian rule. This refugee group was placed in a rural area in close proximity to local people, for instance, on farms. The University of Joensuu organized a research project, the objective of which was to study the adaptation of this refugee group. The research project was divided into three parts: the first part addressed the social networks of Bosnian refugees and their integration into a Finnish community, the second focused on the villagers' attitudes towards Bosnians, and the third looked at the education of Bosnian children. Among Bosnian refugees, there were children aged 12-15, and the municipality organized their education by setting up an elementary instruction group for them for six months.

This paper came out of my thesis study, in which I described the initial period of the daily life of Bosnian children at school, and the social interaction in the group by means of qualitative methods. Through the description of everyday life, I tried to find out how the goals set for the education of refugees were achieved (Asikainen 1994). 
Despite the "good will" and the goals emphasizing the importance of preserving immigrants' own language and culture, the initial period seemed to be a process in which the contradiction between the goals and the resources for reaching them directed the work of the people dealing with the education of Bosnian children. In their daily work, the goals of the workers were changed to emphasize the adaptation of Bosnian children into the Finnish school and society. The curriculum, resources and daily work constitute a whole which supports the aim to assimilate refugee and immigrant children into Finnish society. These results themselves were not surprising, and my research process revealed the questions and problems related to refugee identity.

The Bosnian refugee children and adolescents have been in Finland for four years. My field study focuses on adolescent girls of this refugee group. The data collection methods I used include the collection of refugee stories, and participant observation. The objective of my study is to examine the constitution of identity in exile, in particular, the use of ethnicity in the constitution of social identity. In this paper, I will first discuss the refugee experience, and second, the narrative constitution of identity. Through an episode in seventeen year old Hajra's story, I illustrate a narrative constitution of refugee identity as an alternative expression of the identity of an adolescent girl.

\section{Refugee Experience}

War changes people in profound ways. It changes their perceptions of themselves, other people and the world. The threat in a war is first of all external, but the effects of breaking up internal security and the changes in identity influence people's lives more profoundly, and are more difficult to process. Refugees experience loss, culture change and regeneration. Flight involves insecurity and instability, and refugees have to adjust to rapidly changing situations, for instance, residence in refugee camps and resettle- ment in places with alien cultures. In exile the refugees are safe physically, but the war affects their life continuously through the experiences of violence, escape and exile. Hajra told me

When we came to Finland, we immediately asked if we can go back when it is possible. They said, "You can go back, but you have no place to go to." My father says, "When peace comes, we can go back, but where? We have no place to go. We do not know where to go and where all our domestic animals have gone ..." Father always said, "We can go back tomorrow, or the next day, but we can't go back, because there is no peace."

The Bosnian war contributed to the increase in the awareness of ethnicity and the ethnoreligious affiliation of the Bosnian Muslims. To the generations who grew up in the fifties and sixties, ethnicity (for example, names that reveal ethnoreligious affiliation) was not an important marker of identity and family background. But in the eighties, itstarted to become more important for young people (Bringa 1995, 3). During the war, ethnic groups and ethnic traits were said to be the reason for the violence. As discussed before, ethnicity and "ethnic group" were redefined, and they were used as a factor to mobilize people. History was rewritten in Serbian and Croatian writings in a way that made the Muslims alien: we have always been here, but the Muslims were not until 1400s (Fine 1993, 2). Nationhood was defined as a homogeneous group, which has common roots and the right to a certain defined area.

Thus, the Bosnian war and exile caused by war, produced homelessness, ethnicity and new identities. War also produces a sense of otherness and forces people to see diversity and cultural differences (Mortland 1994, 8). Hajra talked about the atmosphere in her school just before war started, and the attitudes of her classmates towards her:

We had many (Serbian children in our class) because the village was their village, and we used to go to school there and study the Russian language. The village in which my aunt lived they called it $\mathrm{K}$. There were more Muslims than Serbs, but where we lived, there were more Serbs than we Muslims were.

I asked if they had talked about the war with their classmates:

To us they do not tell anything, they say they talk with each other, those Serbs. To us they do not tell anything. When we came to school, they stayed silent, but they talk with each other. But we are listening, we listen to what they say and what their parents say ...

Hajra said that before the war, and before they told it on TV who is a Muslim and who is a Serb, they did not know whether someone was a Serb, a Muslim or a Croat, and they all used to play together. Yet when war came, they learned to know.

\section{Narrative Constitution of Identity}

People tell stories all over the world: tales, memories, rumours and jokes, true stories, personal experience narratives and family stories. Stories and narratives are accommodated to the context, which both create and restrict these narratives. In the case of refugees, refugee stories are told, for instance, in situations where explanations for being "here" (in exile) are needed.

Narratives are told for different reasons. For example, people want to share their experiences and create a sense of togetherness, or they want to organize their experiences. The narratives told in the family context are also told to create family identity and an identity for the members of the family. Life history narratives, in particular, create and recreate a person's identity (Stahl 1977, 33). As discussed before, narratives are used in a war, for instance, to mobilize groups and to justify the action.

In this paper, narrative is considered to be an ontological part of social life. People come to know, understand and make sense of the social world through narrative. They tell narratives for themselves and for other people about themselves, about other people and about different kinds of events. 
People create their social identities through narrative. We come to be who we are by being located or placing ourselves in social narratives (Somers 1994, 606).

In narrative constructions, we can distinguish four different features which are particularly relevant to the social sciences. These are:

1.) relationality of parts,

2.) causal emplotment,

3.) selective appropriation, and

4.) temporality, sequence and place.

Together, these dimensions suggest that narratives are constellations of relationships, embedded in time and space, constituted by causal emplotment. Unlike the attempt to produce meaning by placing an event in a specified category, narrativity precludes sense-making of a singular isolated phenomenon. Narrativity demands that we discern the meaning of any single event only in temporal and spatial relationship to other events.

The relationality of parts turns events into episodes, whether the sequence of episodes is presented or experienced in any chronological order. This is done by emplotment. Emplotment gives significance to singular events or independent instances and translates events into episodes. The plot is not necessarily chronological, but it is thematic. We can see the plot as a logic or syntax of the narrative. Another crucial element of narrativity is its evaluative criteria. We need selective appropriation in constructing narrative. We have to choose which events, experiences and social factors are important. A plot is thematic, and the primacy of some narrative theme or competing themes determines how events are processed, and what criteria will be used to prioritize events and render meaning to them.

Here, Hajra responded to my questions in regard to how she first recognized that things had changed, that things were not as they used to be:

It was first on TV, in the news, that they were coming, the Serbs. Then my uncle called and told us that there would be a war coming, and that we would have to leave our home and come to Croatia and leave everything, home, the cows, etc. Father told us that our uncle was lying that we couldn't go there, and why should we? And that the war was not coming. Mother visited the town, and there all the Serbian women said that the war was surely coming, maybe tomorrow or the next day. They all knew, but we didn't know anything. Then we went to school, we saw a helicopter that brought soldiers and guns. The guns they gave to our neighbours, who were Serbs. We had seen this many times, and we told our father and mother. Our parents went to see and they saw the guns and everything, but father said that surely they gave the guns to our neighbours, because they were in the army. He didn't think that the war would come at all. But our mother had understood that the war would come. My sister had heard all the classmate talking in the school, that the war was coming.

In Hajra's story, we can say that one thematic plot is Hajra's sense of being made invisible and a victim. Hajra was a good pupil. The story presents a picture of a child who sees threatening things happen and does not understand what is going on. Repeatedly Hajra says that they did not know anything; the Serbs did know but did not tell Hajra or her family. Hajra's classmates used to talk and play with Hajra, but when the war started, they ignored her, because she had been revealed as an enemy through the news on TV. Hajra's parents had become victims; they could not believe the war would come to their village. Hajra and her parents lived their daily life with their neighbours, who were Serbs; they worked together and celebrated together. When war started, they were made alien by their neighbours:

Every day they [neighbours] said to us, "The war is not coming, peace will come, we won't shoot you. You can come to our home when the war comes." And when war started, they came and killed our father, the one who had said that the war was surely not coming.
Hajra's story serves as an alternative expression of identity in Hajra's social networks and identities in exile. Hajra told her story to me after her three-year stay in Finland as a refugee. When she left Bosnia, she was fourteen years old. Hajra also told other stories about her life in Finland as a Bosnian girl, or as a North-Carelian girl.

We talked about marrying and dating, and I asked her whether Bosnian girls could date Finnish or Bosnian boys. She told me:

Well, Bosnian boys. We can go (out) with Finnish boys, but we do not know Finnish language or culture. But with Bosnian boys, we can talk our own language. I have a boyfriend in America, and he might come to Finland, but I don't know when. He wants me to marry me, but I don't believe the day will come when I will get married. I always say,"You are lying, you cannot come here," and he says, "I can," every day he says "I can come ..."

I asked where Hajra had met him, and she said:

I have not met him, but he had seen me on videotape. He called here and asked who I was, and one girl phoned me and said, "There is a boy in America who would like you to be his girlfriend for he has no friends there or anything." "Well," I said to the girl, "you can give my telephone number and address to him." And now, he writes me and calls me everyday, and talks with me for about an hour.

\section{I said: "Oh dear, it is expensive!"}

Yes it is! Well, I said (to him), "It is -expensive to call," but he said, "It is not expensive, for you are my girlfriend" ... But I don't understand ... I don't know where to go, whether to go... One boy lives in Oulu, the other one in Mikkeli. I don't know whether to stay in Oulu, Mikkeli or go to America!"

Hajra is a beautiful young woman who goes to vocational school and plans to get married when she finishes school. She has Bosnian boyfriends in Finland and in other countries, and they call Hajra and send her presents. Hajra also talks about loneliness and 
the jealousy of her peers, and problems between Bosnian families in North Carelia. The image of Bosnia seems to serve as a place to go to in her thoughts sometimes when daily life is too gloomy and difficult.

Once, when we were sitting at the kitchen table and she was telling me about her experiences and memories, I got the impression that she was looking at a film, or had discovered in her mind once again all that had happened. I wrote in my diary:

Hajra said that the war was bad, that many people had died, that they had lost their homes, gardens and everything. She looked sad and thoughtful. I got the impression that she had quickly discovered what had happened: Their life was like that there, having orchards and everything, but now she is here, living this life.

\section{Conclusion}

The concept of narrative identity emphasizes the subjectivity and the variety of identities. The narrative identity approach rejects the tendencies of identity theories to normatize identities and to categorize them. The narrative identity approach embeds the actor within relationships and stories that shift over time and place. Through refugee stories, we can find the identity of a refugee, which is enclosed with the experiences of both victim and survivor. Refugee identity is transnational. It is affected not only by former identities and culture, and present influences from the host country, it also includes refugees' relations to other refugees in diaspora. The refugee experience can serve as a mirror reflecting new and changing identities; and conversely, ethnicity can serve as a mirror to reflect the refugee experience.

We know what happened in Yugoslavia on a large scale: people had to leave their homes and flee to foreign countries. We also know that the media was used in conveying propaganda and mobilizing people. Hajra's story serves as an interpretation of the events, but it is also a story of the process through which an adolescent be- came first a refugee, and then became aware of her own and of other peoples' ethnicity. Hajra was endowed with the identity of a refugee on the day she had to leave her home, and the identity of a Bosnian girl on the day she came to Finland. Hajra is very well aware of cultural differences and the problems which are caused by diverse values and norms. She has the criteria and experience to evaluate both Finnish and Bosnian culture and daily life.

Hajra tells her own story of changing situations and contexts. She uses these stories to organize her experiences and to produce the meaning of events. She also constructs her identity through these stories, and offers changing features or aspects of her identity for a changing audience. Fejös $(1995,86)$ contends that well-structured, epic form of narrative indicates the coping strategy and the use of the narrative in daily life. Hajra's story of escape is similar to the stories I collected from other Bosnian girls. The refugee stories and the stories of escape attest to the existence of the oral collective memory. They also indicate the process of subjective appropriation of history and the collectivity of it.

Although the refugee experience is traumatic and stressful, the process is also rejuvenating. Refugees have resources and coping strategies. By collecting refugee stories, it is possible to examine the processes of identity constitution and the flexibility of identities. It is important to express these features of refugees' identity and to make them visible. Narrative approach enables expressions of multiple subjectivities and identities that are not categorical, but rather, are changing and flexible.

\section{Bibliography}

Asikainen, Eija. 1994. "Bosnian Child at School in Ilomantsi-Qualitative Study on Refugee Education in Finland." Migration 23/24, 7-14.

Bringa, Tone. 1995. Being Muslim the Bosnian Way: Identity and Community in a Central Bosnian Village. Princeton, NJ: Princeton University Press.

Fejös, Zoltan. 1995. "Ethnicity through Regaining Collective Memory." In Encoun- tering Ethnicities: Ethnological Aspects on Ethnicity, Identity and Migration, edited by Teppo Korhonen. Studia Fennica Ethnologica 3. Tampere: Tammer-Paino Oy.

Fine, John V. A. 1993. "The Medieval and Ottoman Roots of Modern Bosnian Society." In The Muslims of Bosnia-Herzegovina: Their Historic Development from the Middle Ages to the Dissolution of Yugoslavia, edited by Mark Pinson. Cambridge, MA: Harvard University Press.

Mortland, Carol. 1994. "Cambodian Refugees and Identity in United States." In Reconstructing Lives, Recapturing Meaning: Refugee Identity, Gender, and Cultural Change, edited by Linda A. Camino and Ruth Krulfeld. Basel: Gordon and Breach.

Radosevic, Slavo. 1996. "The Collapse of Yugoslavia-Between Chance and Necessity." In Yugoslavia and After: A Study in Fragmentation, Despair and Rebirth, edited by David A. Dyker and Ivan Vejvoda. New York: Addison-Wesley Longman.

Räsänen, Matti. 1995. "Displaced Persons: Understanding Human Migration in Europe after the Second World War." In Encountering Ethnicities: Ethnological Aspects on Ethnicity, Identity and Migration, edited by Teppo Korhonen. Studia Fennica Ethnologica 3. Tampere: TammerPaino Oy.

Salo, Mikko. 1995. "Pakolaisten sosiaaliset verkostot: Bosnian pakolaisten integroituminen itäsuomalaiseen kyläyhteisöön." Joensuu: Joensuun yliopisto, Yhteiskuntapolitiikan ja filosofian laitos.

Seppo, Simo. 1996. "Bosnian pakolaisten adaptoituminen ilomantsilaisiin oloihin ja paikallisväestön suhtautuminen." Joensuu: Joensuun yliopisto, Kasvatustieteen laitos.

Somers, Margaret R. 1994. “The Narrative Construction of Identity: A Relational and Network Approach." Theory and Society $23,605-49$.

Stahl, Sandra. 1977. "The Oral Personal Narrative in Its generic Context." In Fabula: Journal of Folktale Studies 18, 18-39. ב

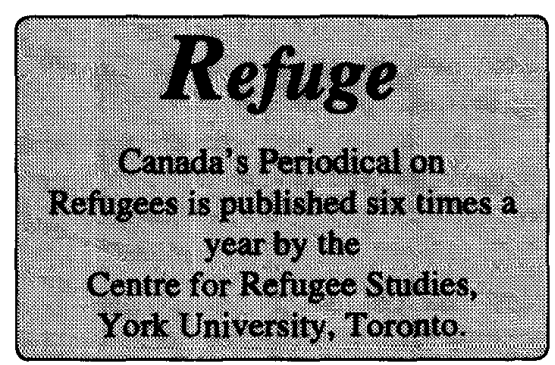




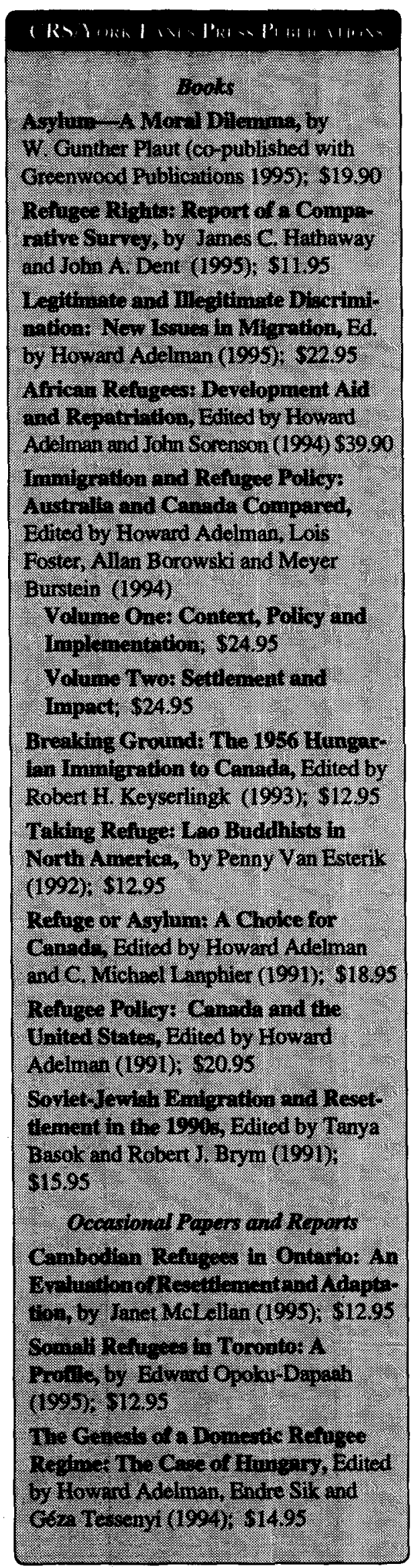

\section{Back Issues of Refuge}

The following is a list of general and thematic issues of

Refuge-Canada's periodical on refugees.

1. Environmental Refugees, Vol. 12, No. 1, June 1992.

2. Discussion of Immigration Bill C-86, Vol. 12, No. 2, July/(Aug.) 1992.

3. General Issue/Refugee Sponsorship, Vol. 12, No. 3, Sept. 1992.

4. Eastern European Refugees, Vol. 12, No. 4, Oct. 1992.

5. The Tragedy of Somalia, Vol. 12, No. 5, Nov./Dec. 1992.

6. The Review of Rejected Refugee Claims in Canada, Vol. 12, No. 6, Jan. 1993.

7. Russia and Central Eurasia, Vol. 12, No. 7, February 1993.

8. Africa Issue: Repatriation, Vol. 12, No. 8, March 1993.

9. General Issue/Globalization, Vol. 13, No. 1, April 1993.

10. Russia and Central Eurasia, Vol. 13, No. 2, May 1993.

11. Special Issue on Sri Lanka, Vol. 13, No. 3, June 1993.

12. Gender Issues and Refugee Law, Vol. 13, No. 4, July/Aug. 1993.

13. Southeast Asian Refugees, Vol. 13, No. 5, Sept. 1993.

14. Mozambican Refugees, Vol. 13, No. 6, October 1993.

15. Russia and Central Eurasia, Vol. 13, No. 7, Nov./Dec. 1993.

16. General Issue/Sudan, Vol. 13, No. 8, January 1994.

17. Integration of Refugees-The Canadian Experience, Vol. 13, No. 9, Feb. 1994.

18. Refugees and Peace in Central America, Vol. 13, No. 10, March 1994.

19. Horn of Africa, Vol. 14, No. 1, April 1994.

20. The Russian Federation, Vol. 14, No. 2, May 1994.

21. The Former Yugoslavia, Vol. 14, No. 3, June/July 1994.

22. General Issue/IRB and Rebuilding Trust/Tamil Immigrants in Canada, Vol. 14, No. 4, Aug./Sept. 1994.

23. Rwandan Crisis, Vol. 14, No. 5, October 1994.

24. Refugee Resettlement in Israel, Vol. 14, No. 6, Nov. 1994.

25. Refugee Women-Part 1: Issues, Vol. 14, No. 7, Dec. 1994.

26. Refugee Women-Part 2: Case Studies, Vol. 14, No. 8, Jan. 1995.

27. The Safe Third Country Concept, Vol. 14, No. 9, February 1995.

28. Special Issue on Chechnya, Vol. 14, No. 10, March 1995.

29. Reformulation of International Refugee Law, Vol. 15, No. 1, 1996.

30. Environment, Development and Refugees, Vol. 15, No. 2, 1996.

31. International Intervention in Refugee Crises, Vol. 15, No. 3, 1996.

32. Early Warning on Humanitarian Crises, Vol. 15, No. 4, 1996.

33. Child Refugees, Vol. 15, No. 5, 1996.

34. Global Settlement Services, Vol. 15, No. 6, 1997.

35. Early Warning and Early Response, Vol. 16, No. 1, May 1997.

36. Uprooting and Consequences, Vol. 16, No. 2, June 1997.

37. Development-induced Displacement, Vol. 16, No. 3, August 1997.

Single copy: Vol 12, $13 \& 14-\$ 6.50$; Vol 15-\$10. 10 percent discount on 3-9 issues (copies); 20 percent discount on 10 issues (copies) or more. Special discounts are available for students and exclusively volunteer-run NGOs. P. O. accepted.

Please send your orders to:

Centre for Refugee Studies, York University

Suite 333, York Lanes, 4700 Keele Street

North York, Ontario, M3J 1P3, Canada

Fax: (416) 736-5837・ Email: refuge@yorku.ca 


\author{
Refuge \\ Centre for Refugee Studies \\ Suite 322, York Lanes \\ York University \\ 4700 Keele Street, North York \\ Ontario, Canada M3J 1P3 \\ Phone: (416) 736-5663 \\ Fax: (416) 736-5837
}

Email: refuge@yorku.ca

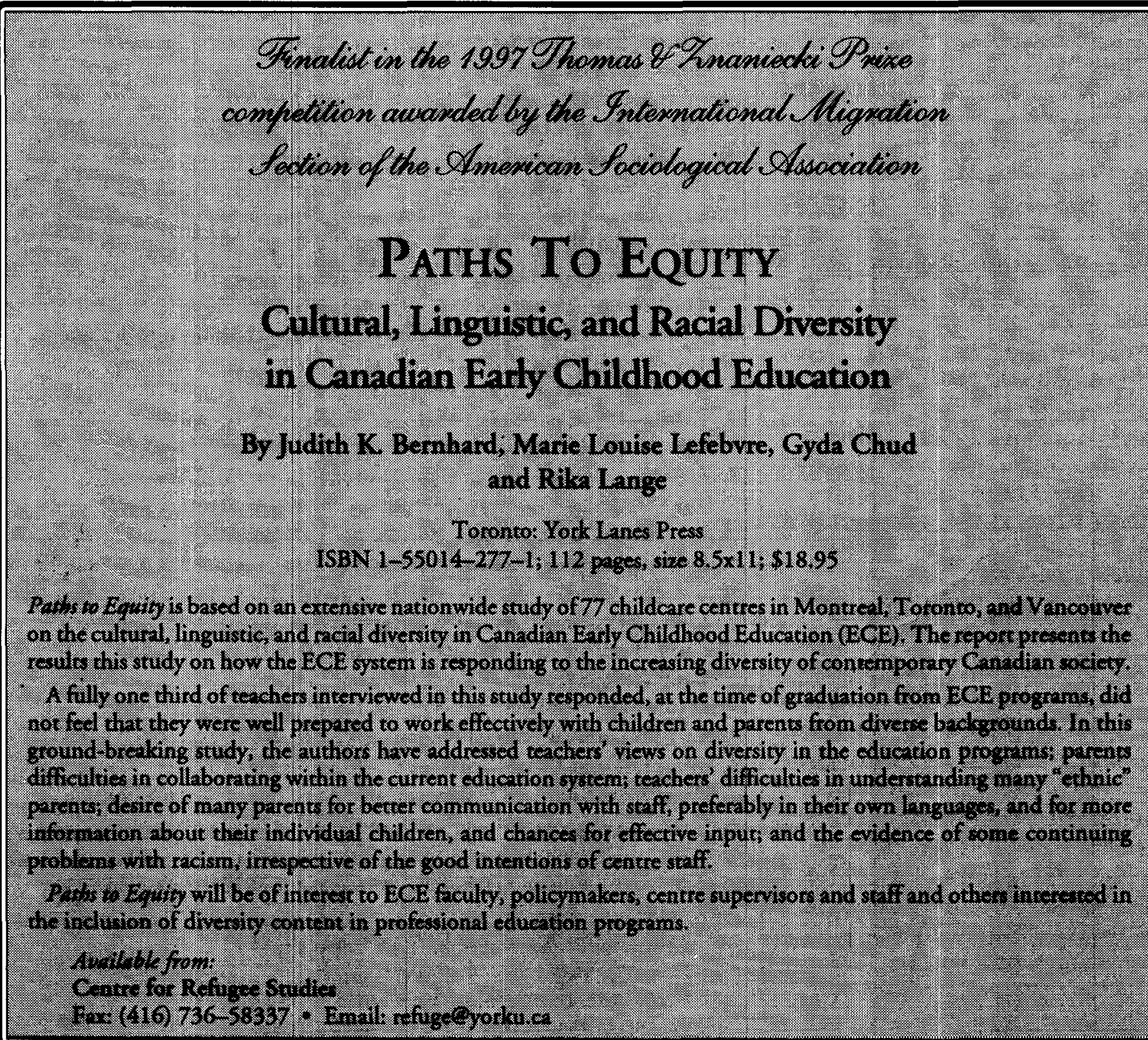

(C) Eija Asikainen, 1997. This open-access work is licensed under a Creative Commons Attribution-NonCommercial 4.0 International License, which permits use, reproduction and distribution in any medium for non-commercial purposes, provided the original author(s) are credited and the original publication in Refuge: Canada's Journal on Refugees is cited. 